\title{
From science to literature: The limits of Aldous Huxley's interdiscursive utopia
}

\section{MAXIM SHADURSKI}

DOI: https://doi.org/10.31577/WLS.2021.13.4.7

The idea of the interdiscursive construction of literature leads back to Peter L. Berger and Thomas Luckmann's The Social Construction of Reality: A Treatise in the Sociology of Knowledge (1966). Famously, this study proposes to treat "social reality" as the sum total of the "common-sense world" of intersubjective everyday life and multiple provinces of subjective experience and objectivized knowledge (Berger Luckmann 1991, 28-29, 34). In an attempt to conjoin the otherwise disparate "social distribution of knowledge" with intersubjectivity, Berger and Luckmann develop the concept of "symbolic universes" $(60,110)$. They designate the latter as specialist fields of knowledge, language, and meaning that at once transcend and affect everyday life, as well as defining intersubjective relations. In the light of this theory, literature acquires the significant role of a mediator between the intersubjective experience of everyday life, on the one hand, and the symbolic universes of science, religion, politics, philosophy, and economy, on the other. As an interdiscursive construction, literature becomes capable of integrating social reality.

Aldous Huxley's writing career exemplifies the interdiscursive construction of literature. This enterprise amounts to an articulation of utopia, an ever-receding horizon where literature integrates social reality by creating a common ground between scientific and literary discourses. As early as the "Subject-Matter of Poetry", an essay collected in On the Margin (1923), Huxley premises his utopia on the allegedly profound receptivity of literature in general, and poetry in particular, to the most recent scientific agenda. He observes:

There would be real novelty in the new poetry if it had [...] taken to itself any of the new ideas and astonishing facts with which the new science has endowed the modern world. There would be real novelty in it if it had worked out a satisfactory artistic method for dealing with abstractions. It has not $(1928,33)$.

As late as his last book Literature and Science (1963), Huxley reinstates the same desideratum in the context of the Two Cultures debate (50). This debate, initiated in the 19th century by his grandfather, the biologist Thomas Henry Huxley, and his great-uncle, the cultural critic Matthew Arnold, took on the scale of a vitriolic and largely overexerted confrontation in the late 1950s and early 1960s. Notoriously, C.P. Snow accused literature of scientific ignorance, while F.R. Leavis ruled against the dehumanizing trappings of science (James 2016). Huxley, in turn, outlines a mutually advantageous rapprochement: 
All that is necessary, so far as the man of letters is concerned, is a general knowledge of science, a bird's eye knowledge of what has been achieved in the various fields of scientific enquiry, together with an understanding of the philosophy of science and an appreciation of the ways in which scientific information and scientific modes of thought are relevant to individual experience and the problems of social relationships, to religion and politics, to ethics and a tenable philosophy of life. And, it goes without saying, between the Two Cultures the traffic of learning and understanding must flow in both directions - from science to literature, as well as from literature to science $(1963,62)$.

Thus, Huxley's interdiscursive utopia equips literature with scientific competences, which bear on the representation of both intersubjective relations and characters' private lives. Literature becomes at once a means and an end: as it displays a wider awareness of the modern world, it gains parity with and informs science. This arrangement promotes literature to the status of a holistic purveyor of what Berger and Luckmann understand as social reality.

Huxley's own fictional writing facilitates literature's interdiscursivity. Most of his novels, from Crome Yellow (1921) to Island (1962), feature discussions of scientific ideas ranging between the establishment of a rational state and the spiritual treatment of social ills. The figure of the scientist takes center stage in an overwhelming number of Huxley's fictions, and one only needs to be reminded of the following characters: the physiologist Shearwater from Antic Hay (1923), the biologist Lord Edward Tantamount and his assistant Illidge from Point Counter Point (1928), the physicist and world controller Mustapha Mond from Brave New World (1932), the sociologist Anthony Beavis from Eyeless in Gaza (1936), the medical researcher Dr. Obispo from After Many a Summer (1939), the botanist Dr. Poole from Ape and Essence (1948), the physics student John Rivers and the Nobel prize-winning physicist Dr. Henry Maartens from The Genius and the Goddess (1955), and the medical doctor Robert MacPhail from Island. Individually, these characters embody Huxley's mutable attitude to science, be it distrust, fascination, or a mixture of both. Yet taken together, they enable interdiscursive exchanges between science and literature, which constitute a recurrent concern in his work.

My previous interventions have emphasized Brave New World's interdiscursive profile by drawing on how the novel engages with strands of national discourse, including the construction of the English landscape (Shadurski 2016a) and sociocultural stereotypes (Shadurski 2018). This article explores how scientific discourses enhance Huxley's interdiscursive utopia, and how that utopia manifests itself in his fiction. Such a dual perspective takes into account several crucial variables attending Huxley's ideas. It requires reading Brave New World alongside relevant historical, intellectual, and critical contexts, in order to identify both the explications and limits of the novel's interdiscursivity. In what follows, I examine Huxley's most prominent and highly ambiguous novel, which harbors its author's ambivalences about science and, in doing so, prefigures what Max Horkheimer and Theodor W. Adorno dubbed the "dialectic of enlightenment" in their eponymous 1947 study. Primarily, though, Brave New World bears the imprint of the 1930s, when scientific ideas purported to inflect social reality in radical and therefore controversial ways, and Huxley's novel probes the applications of these ideas in the form of a eugenically controlled caste 
society. My discussion opens by contextualizing Brave New World in 1920s and 1930s debates about the changing roles of science and the scientist, followed by an overview of relevant criticism; it then proceeds to analyze the novel's treatment of science as a matter of literature's interdiscursivity. This analysis reveals how the co-optation of science to the service of social prejudice marks the limits of Huxley's interdiscursive utopia.

\section{HISTORICAL, INTELLECTUAL, AND CRITICAL CONTEXTS OF INTERDISCURSIVITY IN BRAVE NEW WORLD}

Written during the interwar period, Brave New World played witness to the changing social and cultural importance of science and the scientist. This tendency evidenced itself in literature's enhanced interdiscursivity. In Imagined Futures: Writing, Science, and Modernity in the To-Day and To-Morrow Book Series, 1923-31 (2019), Max Saunders accounts for the emergence and development of a distinctive genre of "speculative non-fiction" which preoccupied itself with the popularization of science in ways accessible to the general public (vii). Comprised of 110 volumes, the To-Day and To-Morrow book series became a landmark during the interwar years, communicating the sense of "radical commencement" in the face of post-Darwinian degeneration and post-World War I despondency (Saunders 2019, 51). As an interdiscursive phenomenon, the series carved out what Saunders terms "a third culture" between science and literature (9). In his estimation, Brave New World derives much of its interdiscursivity from To-Day and To-Morrow, as, in all likelihood, Huxley "was following the series" quite closely (307). Thus, the novel owes its ideas of ectogenesis and Malthusian belts to J.B.S. Haldane's Daedalus; or, Science and the Future (1923); speculations about the misuses of science come from Bertrand Russell's Icarus; or, The Future of Science (1924); hypnopaedia and the feelies hark back to J.D. Bernal's The World, the Flesh and the Devil; An Enquiry into the Future of the Three Enemies of the Rational Soul (1929); and the rendition of Britain as anthropological material resonates with Archibald Lyall's It Isn't Done; or, The Future of Taboo Among the British Islanders (1930). Undoubtedly, Huxley's reading lists surpassed the remit of the book series, and other interdiscursive sources ought to be mentioned, particularly those dealing with eugenics and the exercise of power in a rational society: Alexander M. Carr-Saunders's Eugenics (1926), H.G. Wells, Julian Huxley, and G.P. Wells's The Science of Life (1930), and Bertrand Russell's The Scientific Outlook (1931).

Chronologically, the completion of Brave New World overlapped with the curtailment of To-Day and To-Morrow in 1931. The unrivalled prominence of science went into decline after the Great Depression, which, in Saunders's words, delivered "a blow to confidence in the future more generally" $(2019,341)$. Symptomatically, Brave New World translates the 1930s economic slump into the "year of stability, A.F. 632" (1968, 16). However, Huxley's compensatory gesture gives science and the scientist much less definite reaffirmation. My ensuing discussion shows that they both emerge simultaneously as perpetrators and saviors of social well-being, which does not always reflect the clear-cut distinction between pure and applied science. This peculiarity bespeaks a wider intellectual and sociocultural flux surrounding science before World War II. 
Brave New World's interdiscursivity has been the subject of several key enquiries, most of which testify to the post-World War II discrediting of science. In "Aldous Huxley and Utopia" ("Aldous Huxley und die Utopie", 1955), Theodor W. Adorno has offered one of the earliest critical evaluations of how Huxley's novel presents science as a means to totalitarianism. For Adorno, Brave New World instrumentalizes science in ways that render both politics and economy subservient to a "totally planned state capitalism", where the "system of class relationships is made eternal and biological" (1997, 98-99). Under the banner of civilization, science "lays hands on everything and tolerates nothing which is not made in its own image" (101). In Adorno's estimation, this "linear concept of progress" heralds the contrary of "total enlightenment" and degenerates into irrationality $(113,115)$. Along these lines, Brave New World anticipates Horkheimer and Adorno's earlier work Dialectic of Enlightenment: Philosophical Fragments (Dialektik der Aufklärung: Philosophische Fragmente, 1947), and Adorno does not deny Huxley the "accuracy of imagination" (1997, 115). Indeed, Huxley envisions what Horkheimer and Adorno call "the disenchantment of the world" $(2002,1)$, caused by the victory of science as instrumental reason: "Reason serves as a universal tool for the fabrication of all other tools, rigidly purpose-directed and as calamitous as the precisely calculated operations of material production, the results of which for human beings escape all calculation" (23). As in Brave New World, the "dialectic of enlightenment" turns reason into its opposite, or, in Horkheimer and Adorno's words, the "curse of irresistible progress is irresistible regression" (28). Despite acknowledging Huxley's shrewdness about science, Adorno levels a dismissive critique at Brave New World's ostensible failure to break free from its "repulsive complicity" with the present $(1997,116)$. By this token, the novel grotesquely totalizes science's co-optation by extant capitalist trends and, as a result, grants no sense of a future which would have ushered in a socialist alterity.

Robert S. Baker has taken a more conciliatory line on both Brave New World and its author's preoccupations with science. In "Science and Modernity in Aldous Huxley's Inter-War Essays and Novels" (2001), he affords a nuanced analysis of a raft of scientist characters, which permits him to register the complexity of Huxley's evolving stances on science and historicize them alongside the perceived triumphs of scientific progress in the interwar years. Accordingly, Huxley assessed science "as dangerous; it must be controlled. It is complicit with industry and capitalism. It is the handmaid of social planning and social planning is, at best, both necessary and dangerous" (36). Baker records how such reservations find their reflection in Huxley's novels, particularly in the characters whose applications of science bring out sadistic tendencies, with Brave New World's Mustapha Mond epitomizing "the more self-assured and domineering technocratic sadist" (36). Crucially, Baker distinguishes between Huxley's wariness about applied science and his growing fascination with the ontological mysticism of pure science (58). This distinction remains problematical in Brave New World and plays a pivotal role in Huxley's later writings, especially Island (Shadurski 2016b, 96104).

Unlike Baker, Joanne Woiak avoids vindicating Huxley's views of applied science and their representation in Brave New World. In "Designing a Brave New World: 
Eugenics, Politics, and Fiction" (2017), she reads the novel as "a satire on contemporary culture, a prediction of biological advances, a commentary on the social roles of science and scientists, and a plan for reforming society" (249). Woiak's reading discloses Huxley's paralyzing fear of the democracy of the lower classes, whom he identified with dysgenic types. For Woiak, Huxley devised his World State as a eugenically stratified society in order to circumvent the disappearance of what he deemed to be "our best stock" (250). Accordingly, Huxley's social prejudice mirrored "the predominant factor in British eugenics" during the interwar years (255). Unlike Adorno, Woiak evaluates Brave New World on its own terms. Instead of vexing negative about the novel's blatant flaws, she notices what it has achieved: "It offers a sophisticated critique of how scientific knowledge emerges from and in turn serves the social, political, and economic agendas of those in power" (256). This approach reaffirms Brave New World's interdiscursive parameters; it also invites considerations of how Huxley's utopia comes to terms with the dystopia of a class-ridden, hedonistic, and technocratic society in the context of its own social and intellectual history. The next two sections examine the novel's two interdiscursive aspects: its provisional mediation of progress and regression, and its full endorsement of eugenic controls.

\section{PROVISIONAL MEDIATION OF PROGRESS AND REGRESSION}

Brave New World conceives of the post-Fordian World State as the outcome of applied, rather than pure, science. Applied science has drawn the demarcations between civilization and savagery, distinguished itself from pure science, and acquired mass circulation. The novel undertakes to deconstruct the ostensible progress made by applied science. This endeavor falls short of mediating every duality that accompanies it and discloses Huxley's sympathies for pure science, which would serve the interests of a select coterie of upper-casters. Huxley shares such caveats with some of his contemporaries, on both left and right of the political spectrum. In the aforementioned Daedalus, J.B.S. Haldane warned about "the tendency of applied science [...] to magnify injustices" $(1924,85)$. To the same effect, Bertrand Russell alerted the reader of The Scientific Outlook to a prospective society whose governors would withhold science from "ordinary men" $(1931,253)$. Despite styling himself as an enemy of leftist thought, Wyndham Lewis went further to dismiss applied science as a "romance of destruction" (1926, 258). In The Art of Being Ruled (1926), he worried that, in the hands of average people, science would become "some sort of weapon or tool at once, to get at food with, or sanctimoniously rip up their neighbour" (118). These concerns find interdiscursive resonances in Brave New World.

The novel negotiates progress and regression through the character of Mustapha Mond, the world controller for Western Europe. The first duality transpires in his historical excursus about the period preceding his rule. Mond recounts the allegedly spectacular effects of anthrax bombs, one of the most recent achievements of applied science: "An enormous hole in the ground, a pile of masonry, some bits of flesh and mucus, a foot, with the boot still on it, flying through the air and landing, flop, in the middle of the geraniums - the scarlet ones; such a splendid show that summer!" (Huxley 1968, 53) As Mond takes a perverse delight in the splendor of destruction, 
he evokes the final scene of G.B. Shaw's The Heartbreak House (1919). There, Mrs. Hushabye aestheticizes war: "Did you hear the explosions? And the sound in the sky: it's splendid: it's like an orchestra: it's like Beethoven" $(1957,158)$. Shaw's play lays bare the excesses of civilized refinement, which seeks release in destructive savagery. Brave New World, in turn, discerns savagery in applied science, as it makes havoc seem delightful. In that sense, Huxley renounces Mond's excitement and settles for a contemporary historian's resignation. In Equality (1931), R.H. Tawney commented on his first-hand experience of the Battle of the Somme: "It is possible [...] for a society to be heir to the knowledge of all the ages, and to use it with the recklessness of a madman and the ferocity of a savage" $(1994,212)$. Like Joseph Conrad's Kurtz, Tawney had discovered that civilization possessed a savage "heart of darkness". In its own peculiar way, Huxley's novel blurs the demarcations between civilization and savagery, and presents applied science as the perpetrator of both progress and regression.

The second duality pertaining to progress and regression comes to the fore in the distinction made by Mond between pure and applied science. He repudiates pure science as both "a menace to stability" and a subversive enemy (Huxley 1968, 198). By contrast, he privileges applied science, which he defines as "a cookery book, with an orthodox theory of cooking that nobody's allowed to question, and a list of recipes that mustn't be added to except by special permission from the head cook. I'm the head cook now" (199). Mond's cynical attitude never lacks a fully grounded pragmatism, which additionally discloses his reactionary mindset; he declares: "We don't want to change" (198). In the World State, applied science may only deal with "the most immediate problems of the moment" (200). This line of argument justifies Mond's self-righteous devotion to social stability and other people's happiness. In his 1932 essay "Science and Civilization", Huxley struck a vividly similar chord as a social planner, if not as a world dictator. He called for "a lot of science, well applied", and recommended scientific dictatorship as "the only means for saving humanity from the miseries of anarchy" (Huxley 1994a, 106, 111). On this reading, Mond comes across as Huxley's mouthpiece on the applications of science for the sake of stability. However, Huxley sought to resolve the immediate uncertainties of the 1930s historical situation, while Mond pursues stability as an end in itself. Subsequently, progress becomes a default position which forecloses other possibilities, including those offered by pure science, and spells regression for society at large.

The third duality related to progress and regression plays itself out in the checks that Mond imposes on the availability of pure science. He is shown to censor a scientific tract titled quite ambitiously "A New Theory of Biology":

He sat for some time, meditatively frowning, then picked up his pen and wrote across the title-page. "The author's mathematical treatment of the conception of purpose is novel and highly ingenious, but heretical and, so far as the present social order is concerned, dangerous and potentially subversive. Not to be published." He underlined the words (1968, 158-159).

Even though Mond has the acumen to acknowledge the novelty and ingenuity of this "masterly piece of work", he trades it for the stability of the order on whose behalf he acts. Especially, he lingers on the conception of purpose, by which the tract pur- 
ports to displace the extant idea of universal happiness among the upper castes. The extradiegetic narrator informs us of Mond's train of thought: "It was the sort of idea [...] that the purpose of life was not the maintenance of well-being, but some intensification and refining of consciousness, some enlargement of knowledge" (159). No matter how much Mond accepts the purely scientific premises of the tract, he refuses to admit any prospect of their practical application. As a result, he retrieves such knowledge from mass circulation, and this act mediates progress into regressive conformity with the status quo.

Nevertheless, Mond's policy makes significant concessions for the upper-casters, in which sense it deviates from Bertrand Russell's warning. In The Scientific Outlook, Russell prognosticated that rational societies would suppress revolt among the "ill-disciplined intelligence" by consigning dissenters to the lethal chamber (1931, 257). By contrast, Huxley's Mond contemplates dispatching the tract's author to "the Marine Biological Station of St. Helena" and placing him under supervision there (Huxley 1968, 159). A comparable plan exists for Helmholtz Watson, a lapsed propaganda technician and budding poet, whom Mond intends to exile to the Falkland Islands (202). Such dispensations permit a fuller glimpse into Huxley's interdiscursive utopia, which sets off islands for the potential activity of scientists and poets. Banished from the frontiers of civilization, both pure science and poetry have the potential to ensure a different version of progress, one that supersedes the existing dystopia of Mond's World State. At the same time, though, Huxley entertains such visions of alterity on elitist principles of privilege and exclusion. His coterie of scientists and poets are members of the genetically enhanced personnel, and his interdiscursive utopia owes itself to the applied science of eugenics.

\section{FULL ENDORSEMENT OF EUGENIC CONTROLS}

During the 1930s, the rise of the Nazis to power in Germany and the ensuing adoption of racial purity laws produced a ripple effect on British eugenics. In Demography and Degeneration: Eugenics and the Declining Birthrate in Twentieth-Century Britain (1990), Richard A. Soloway has noted a gradual shift from nature to nurture in scientific enquiry and public debate taking place at that time. According to him, hereditarian beliefs dominated the 1920s agendas. Yet a new "eugenic and racial conscience" emerged in the second half of the 1930s, largely due to universal education and the scientifically verified promotion of healthy and useful stocks (310). Regardless of this general trend in British eugenics, Huxley maintained a hereditarian position, which explains his hierarchical thinking and social prejudice against the poor orders of society. In "What is Happening to Our Population?" (1934), he lamented that the "half-wits" from the lower classes would soon overpopulate Britain and sanction "a squalid and humiliating conclusion to English history" (1994b, 150). Additionally, Huxley's concern reflected a much wider contemporary anxiety about degeneration. To that end, H.G. Wells and his co-authors of The Science of Life speculated about the institutionalized extermination of defectives: "A rather grim Utopia might be devised in which for some generations [...] inbreeding would be made 
compulsory, with a prompt resort to the lethal chamber for any undesirable results" $(1931,307)$. Set against this mutable historical and intellectual background, Brave New World spells out its own applied science of eugenics, whose interdiscursivity calls for investigation.

Within its dystopian parameters, Huxley's novel implements a highly elaborate system of eugenic controls. The World State presents a caste-ridden society whose demographic constitution allows for the existence of a full range of intelligences, from Alpha through Beta to Gamma, Delta, and Epsilon. Brave New World begins with a striking description of a "squat grey building of only thirty-four stories" (1968, 15). Through the complex technologies of test-tubing, embryonic nutrition, and hypnopaedia, the Central London Hatchery and Conditioning Centre perpetuates the World State's caste structure. Alpha-Pluses evolve from one division of a fertilized egg and, consequently, come to belong to the least numerous elite. They excel both intellectually and physically, just as Mond, Helmholtz, and the biological tract's author do. By contrast, Epsilons develop from a manifold division of the same egg, which sets them apart for a robotic life of identical factory workers. The novel depicts Gammas, Deltas, and Epsilons as a nondescript mass: "Like aphides and ants, the leafgreen Gamma girls, the black Semi-Morons swarmed round the entrances, or stood in queues to take their places in monorail tram-cars" (66). When occasionally individualized, like the liftman at the Hatcheries and Conditioning Centre, the lower castes are little more than simian creatures who function in the "twilight of [their] own habitual stupor" (63). Indeed, the distribution of intelligence drops to a zero at the bottom line of the caste spectrum; as one character remarks, "But in Epsilons, [...] we don't need human intelligence" (25). Such designs benefit the upper castes, whose privileged position in the World State is fully contingent on eugenic controls. If read as a literary response to the interwar period's degenerative anxiety, Brave New World endorses eugenics as an expedient force in safeguarding stability and protecting the best genetic stocks.

However, Huxley complicates this interdiscursive arrangement at the levels of plot development and literary allusion. Elaborate as they are, the World State's eugenic controls prove insufficient in containing the elite's transgressive impulses, in which case Mond confronts a seemingly regular dilemma. As with the biological tract's author, he has to execute Alphas in ways that at once sustain stability and save the culprit from extermination. For that purpose, the World State administers punishment in the form of exile to the islands. In Mond's explanation, the islands include "the most interesting set of men and women to be found anywhere in the world. All the people who, for one reason or another, have got too self-consciously individual to fit into community-life"; he adds further: "It's lucky [...] that there are such a lot of islands in the world. I don't know what we should do without them. Put you in the lethal chamber, I suppose" (200-201). Brave New World dramatizes the banishment of the malcontents by rehearsing a classical trope. In Plato's dialogue about the Republic, Socrates ordered the poets to leave the city because of their vain impressions of the world, which threatened to cause social unrest. 
Additionally, Huxley's novel reanimates two utopian satires from the late Victorian era: Samuel Butler's Erewhon: or, Over the Range (1872) and Erewhon Revisited Twenty Years Later (1901). In 1934, Huxley wrote an introduction to an exclusive edition of Erewhon, where he praises Butler for the innovative contribution he made to eugenic controls. Indeed, being the satirical inversion of Britain, the Erewhonian society predicates its order on two interrelated injunctions. On the one hand, it criminalizes disease: if anyone displays the symptoms of a hereditary or transferable malady, they will likely face removal from society and a life-time ban on procreation. Conveniently, Huxley's introduction glosses over the fact that Erewhonian punishments inflict death, which absolutizes the significance of physical health and beauty. On the other hand, though, the Erewhonians medicalize crime, attributing its causes to potentially treatable psychological disorders. In Huxley's appraisal, “The Erewhonian philosophy robs mankind of one of its most ancient excuses for cruelty. If criminals are merely sick, then our sadism towards them remains unmitigated sadism and cannot disguise itself as a zeal for righteousness" (1934, xix). Thus, be it criminalized disease or medicalized crime, Butler's Erewhon prescribes curing social and individual ills by segregation. Huxley adopts Erewhonian eugenic policy in Brave New World, and segregation reigns supreme in the World State. It stratifies society and undercuts the fabric of the world, while divisions feed off the social prejudice and hierarchical thinking of a eugenically engineered elite. Unlike his contemporaries, Huxley spares both the lapsed Alphas and the witless Epsilons from the lethal chamber. Yet their parallel, impenetrably segregated existences detract considerably from his interdiscursive utopia.

\section{CONCLUSION}

Being a spinoff of Berger and Luckmann's theory, interdiscursivity directly correlates with intersubjectivity. It ensures that the experience of everyday life becomes enriched with the competences from specialist symbolic universes. Social reality emerges at the intersections of interdiscursivity and intersubjectivity. Literature may lay a valid claim to a holistic representation of that reality, if it amalgamates multiple discourses and folds them into intersubjective relations. By this logic, Huxley's interdiscursive utopia achieves significant formal results, especially because it imaginatively renegotiates scientific knowledge and literary allusion. However, this form of interdiscursivity stays within the hermetic confines of an insulated symbolic universe. Its maintenance depends on the selective adaptations of both pure and applied science, which serve the interests and flourishment of a privileged caste. Huxley's interdiscursive construction of literature finds its limits in the dystopia of segregated intersubjective relations. Like every utopia, the intersubjectivity of Brave New World remains an ever-receding horizon, which Huxley's later fiction seeks to embrace. 


\section{LITERATURE}

Adorno, Theodor W. [1955] 1997. "Aldous Huxley and Utopia." In Prisms, Theodor W. Adorno, trans. by Samuel Weber - Shierry Weber, 95-116. Cambridge, MA: MIT.

Baker, Robert S. 2001. "Science and Modernity in Aldous Huxley's Inter-War Essays and Novels." In Aldous Huxley: Between East and West, ed. by C.C. Barfoot, 35-58. Amsterdam - New York, NY: Rodopi. DOI: https://doi.org/10.1163/9789004483569_006.

Berger, Peter L. - Thomas Luckmann. [1966] 1991. The Social Construction of Reality: A Treatise in the Sociology of Knowledge. 6th Edition. Harmondsworth: Penguin Books.

Bernal, John Desmond. 1929. The World, the Flesh and the Devil; An Enquiry into the Future of the Three Enemies of the Rational Soul. London: Kegan Paul.

Carr-Saunders, Alexander M. 1926. Eugenics. London: Williams and Norgate.

Haldane, J.B.S. 1924. Daedalus; or, Science and the Future. London: Kegan Paul.

Horkheimer, Max - Theodor W. Adorno. [1947] 2002. Dialectic of Enlightenment: Philosophical Fragments, ed. by Gunzelin Schmid Noerr, trans. by Edmund Jephcott. Stanford, CA: Stanford University Press.

Huxley, Aldous. 1928. On the Margin: Notes and Essays. London: Chatto and Windus.

Huxley, Aldous. 1934. "Introduction." In Erewhon, Samuel Butler, xv-xxii. New York: Pynson.

Huxley, Aldous. 1963. Literature and Science. London: Chatto and Windus.

Huxley, Aldous. 1968. Brave New World. Brave New World Revisited. London: Heron.

Huxley, Aldous. [1932] 1994a. "Science and Civilization." In The Hidden Huxley: Contempt and Compassion for the Masses 1920-1936, ed. by David Bradshaw, 105-114. London: Faber and Faber.

Huxley, Aldous. [1934] 1994b. "What is Happening to Our Population?" In The Hidden Huxley: Contempt and Compassion for the Masses 1920-1936, ed. by David Bradshaw, 147-158. London: Faber and Faber.

James, Frank A.J.L. 2016. “Introduction: Some Significances of the Two Cultures Debate." Interdisciplinary Science Reviews 41, 2-3: 107-117. DOI: https://doi.org/10.1080/03080188.2016.1223651.

Lewis, Wyndham. 1926. The Art of Being Ruled. London: Chatto and Windus.

Lyall, Archibald. 1930. It Isn't Done; or, The Future of Taboo Among the British Islanders. London: Kegan Paul.

Russell, Bertrand. 1924. Icarus, or, The Future of Science. London: Kegan Paul.

Russell, Bertrand. 1931. The Scientific Outlook. London: George Allen and Unwin.

Saunders, Max. 2019. Imagined Futures: Writing, Science, and Modernity in the To-Day and To-Morrow Book Series, 1923-31. Oxford: Oxford University Press. DOI: https://doi.org/10.1093/ oso/9780198829454.001.0001.

Shadurski, Maxim. 2016a. "Flowers and a Landscape Were the Only Attractions Here': The England of Wells and Morris in Aldous Huxley's Interpretation." In Utopias and Dystopias in the Fiction of H.G. Wells and William Morris: Landscape and Space, ed. by Emelyne Godfrey, 223-239. London: Palgrave Macmillan.

Shadurski, Maxim. 2016b. Utopiia kak model mira: granitsy i pogranichiia literaturnogo iavleniia / Utopia as a World Model: The Boundaries and Borderlands of a Literary Phenomenon. Siedlce: Wydawnictwo IKR[i]BL. Accessed June 29, 2021. http://hdl.handle.net/11331/1995.

Shadurski, Maxim. 2018. "Nation and Utopia: Images of England in Brave New World." In Imagology Profiles: The Dynamics of National Imagery in Literature, ed. by Laura Laurušaite, 68-78. Newcastle upon Tyne: Cambridge Scholars.

Shaw, G.B. [1919] 1957. The Heartbreak House. Harmondsworth: Penguin Books.

Soloway, Richard A. 1990. Demography and Degeneration: Eugenics and the Declining Birthrate in Twentieth-Century Britain. Chapel Hill: The University of North Carolina Press.

Tawney, R.H. 1994. Equality. Vol. 1. London: Pickering.

Wells, H.G. - Julian Huxley - G.P. Wells. 1931. The Science of Life. London: Cassell.

Woiak, Joanne. 2017. “Designing A Brave New World: Eugenics, Politics, and Fiction.” In Twentieth-Century Literary Criticism, Vol. 336, ed. by Lawrence J. Trudeau, 248-264. Farmington Hills: Gale/Cengage Learning. 
Literature. Science. Interdiscursivity. Utopia. Aldous Huxley. “Brave New World.“

Throughout much of his writing career, Aldous Huxley contributed to the interdiscursive construction of literature as a utopia, a common ground between scientific and literary discourses. This article explores both the explications and limits of Huxley's interdiscursive utopia, focusing primarily but not exclusively on his most famous and highly ambiguous novel Brave New World (1932). Read against the background of pertinent criticism and contextualized in 1920s and 1930s debates about the changing prominence of science and the scientist in Britain, Huxley's enterprise manifests a considerable preserve of social prejudice and hierarchical thinking. This circumstance detracts substantially from the interdiscursivity of his utopia and compromises literature's claim to a holistic representation of social reality.

\author{
Dr. Maxim Shadurski \\ Institute of Linguistics and Literary Studies \\ Siedlce University of Natural Sciences and Humanities \\ Żytnia 39 \\ 08-110 Siedlce \\ Poland \\ maxim.shadurski@uph.edu.pl
}

ORCID: https://orcid.org/0000-0001-7751-4673 